\title{
MULHERES, UMA EXPERIÊNCIA DE DORES E RETROCESSOS PANDÊMICOS: A DIFUSÃO DO CUIDADO E DA SOLIDÃO
}

\author{
WOMEN, AN EXPERIENCE OF PANDEMIC PAIN AND SETBACKS: THE \\ DIFFUSION OF CARE AND LONELINESS
}

\begin{abstract}
RESUMO: Este artigo reflete as condições do ser mulher na sociedade, assim como, os atravessamentos e experiências causadas por conta do cenário devastador da pandemia por COVID-19. Em que a sobrecarga do feminino, a divisão sexual do trabalho e os marcadores estruturantes sociais sobre os papéis masculinos e femininos, contribuíram nas trajetórias do cuidar dirigindo esta tarefa ao feminino. Desta maneira, com a conjuntura pandêmica a violência de sobrecarga que se inicia no lar, agora mede forças com o espaço público em que o contexto do Home Office reúne os dois espaços e funções opostas em um resultado exaustivo e adoecedor paras as mulheres, que são afetadas de maneiras distintas levando em conta os aspectos raciais e de classe. Diante disso, o artigo retrata como a esfera do lar é considerado um trabalho não remunerado, mas que, sobretudo, ampara as estruturas do patriarcado e consequentemente o capital simbólico. Com a finalidade de analisar e identificar as construções sociais e simbólicas sobre o papel do cuidado de modo descritivo e qualitativo pautado nos estigmas sociais ao gênero e sobre a solidão da pandemia do cuidado. Para isso, serão utilizados referenciais teóricos a partir de vozes feministas da contemporaneidade, dispostas em seções, com o objetivo de compreender as cargas seculares e a solidão das mulheres, especialmente negras, carregadas de "Dororidades".
\end{abstract}

PALAVRAS-CHAVE: COVID-19; Divisão sexual do trabalho; Experiências; Sobrecarga do feminino; Solidão.

ABSTRACT: This article reflects the conditions of being a woman in society, as well as the crossings and experiences caused by the devastating scenario of the COVID19 pandemic. In which the female overload, the sexual division of work and the social structural markers on male and female roles, contributed to the trajectories of care, directing this task to the female. In this way, with the pandemic situation, the overload

\footnotetext{
${ }^{1}$ Bacharela em Cultura, Linguagens e Tecnologias Aplicadas (UFRB), aluna especial de mestrado do Programa Multidisciplinar de Pós- Graduação em Estudos Étnicos e Africanos (CEAO-UFBA), Pósgraduanda em Direitos Humanos, Gênero e Sexualidade (DIHS/ENSP/FIOCRUZ) integrante do grupo de pesquisa Direito e Sexualidade (UFBA- CNPq), integra a equipe Promotoras Legais Populares (Coletivo Madás - UFBA) integrante do Núcleo de Pesquisa e Extensão em Culturas, Gêneros e Sexualidade (NuCuS- UFBA) nas linhas de Gênero e Sexualidade na Educação e Processos de Subjetivação, Raça, Gênero e Sexualidade. E-mail: anacarolineos53@gmail.com
} 
violence that starts at home, now measures forces with the public space in which the Home Office context brings together the two opposite spaces and functions in an exhausting and sickening result for women, who are affected in different ways taking into account racial and class aspects. Therefore, the article portrays how the home sphere is considered an unpaid job, but that, above all, supports the structures of patriarchy and, consequently, symbolic capital. In order to analyze and identify the social and symbolic constructions on the role of care in a descriptive and qualitative way based on the social stigmas of gender and on the loneliness of the care pandemic. For this, theoretical references will be used from contemporary feminist voices, arranged in sections, with the aim of understanding the secular burdens and loneliness of women, especially black women, loaded with "Sorrows".

KEYWORDS: COVID-19; Sexual division of labor; Experiences; Female overload; Loneliness.

\title{
1 INTRODUÇÃO
}

\author{
"TRAJETÓRIAS \\ Trajes de histórias \\ Trazes mulheres fora da história \\ Trajes de um patriarcado \\ Trazes no meu corpo \\ Trajes de dores \\ Trazes trajes de um tempo... \\ Trazes trajetórias de um mundo pandêmico \\ Trajes os meus direitos e destrave-os deste silêncio \\ Trazes o trânsito do gênero, a costura da raça \\ atravessada nas divisões de classe. \\ Trazes o não retrocesso, do trânsito da minha, da \\ sua trajetória. \\ (Ana Caroline Oliveira da Silva, 2021)."
}

Com essa provocação, começo este artigo com uma oferta poética sobre mulheres em movimento, trajetórias e sentidos. E, portanto, trajetórias essas romantizadas pela construção patriarcal que vivemos seja sobre as nossas narrativas, ou sobre os silêncios que nos assombram. Começo aqui pensando, portanto, a categoria mulheres e seus atravessamentos que marcam de forma tão dissidente nossas experiências e intersecções de gênero, raça e classe movidas principalmente sobre o que se é pensado e construído quanto à divisão sexual do trabalho e a carga atribuída às mulheres. Em uma ilusão que contraí saldos altíssimos e imensuráveis, 
tendo em vista o capitalismo patriarcal como forma de justificar a falsa liberdade da força de trabalho das mulheres na esfera pública e privada.

"Não se nasce mulher, torna-se mulher" essa famosa frase da filósofa e feminista francesa Simone de Beauvoir em sua publicação original segundo sexo (1949), refere-se que sexo biológico é diferente de gênero. Este primeiro se trata de uma condição imposta ao nascimento e o gênero é uma construção social, ou seja, coletivamente a sociedade constrói o que se espera para este ser social, como por exemplo, o quem vem a ser brinquedo de menina ou de menino, como uma menina e um menino devem se vestir, ou até mesmo se comportar dentro deste sistema social, seja de modo institucional através da educação até as mídias de massa e a cultura do consumo que se adeque aos binarismos sociais.

O debate acerca do ser mulher na sociedade está intimamente ligado a um papel construído pelo sistema patriarcal, que se encarrega de catalogar estereótipos como o da "bela, recatada e do lar" ${ }^{2}$, que inferi e sugere as trincheiras do sistema brasileiro sobre uma visão distópica, patriarcal, branca e heterossexual. Articulando e condicionando os papéis femininos a uma padronização social e midiática branca, condenando a mulher a esfera do lar como: a dona de casa, a cuidadora do lar e dos afazeres domésticos em consonância de uma relação submissa entre o matrimônio e a maternidade, imposta socialmente.

Refletir o Brasil nesta lógica patriarcal é relembrar o Código Civil de 1916, que estabelece como o patriarcado definia a condição de mulher perante a lei neste período, representando um marco de apropriação do corpo feminino como propriedade única e exclusiva do marido e, consequentemente, fadado à esfera do lar

\footnotetext{
2 "Bela, recatada e do lar" tornou-se uma frase com grande repercussão nas mídias sociais, após a exprimeira-dama da época Marcela Temer, uma mulher branca e de classe média casada com o expresidente do Brasil, Michel Temer (mandato de 2016-2018), em uma entrevista a Revista Veja referese que o papel de mulher deveria ser no âmbito da beleza, de comportamento recatado e principalmente na esfera do lar. Inúmeras críticas foram lançadas através das redes sociais com manifestações como "bela, recatada e do bar" e dentre outras frases foram ressignificadas como forma de protesto para dizer que lugar de mulher é no lugar que ela quiser, pois ser mulher não pode ser definido como uma denominação universal, cada mulher possui subjetividades e experiências que as diferem de outras. Como exemplo, ser mulher branca e ser mulher negra de forma alguma poderá ser dimensionado de modo universal já que a raça, o gênero e classe são categorias que se entrecruzam e modificam as experiências de vida e atravessamentos dentro desta perspectiva analítica.
} 
e educação das crianças. Sua conduta na esfera privada era ser casada e dever obediência ao seu marido, o único provedor da casa, que juntamente com a mulher zelavam pela moral e bons costumes da família. O Código Civil de 1916 consistia por lei reiterar a mulher como um objeto feito somente para o lar, deste modo, dispor a uma emancipação feminina era quase uma utopia mediante a tais circunstâncias, principalmente no que tange a mulher no ingresso ao mercado de trabalho ou até mesmo a divisão sexual do trabalho que se difere. De um lado o ingresso ao mercado de trabalho para as mulheres brancas foi uma conquista, do outro para as mulheres negras a esfera do trabalho exploratório era algo comum, logo, suas experiências de emancipação caminhavam em lados distintos.

Em razão disto, neste artigo será discutido como a dominação do masculino sobre o feminino marcam as experiências de mulheres até os dias atuais com alguns referenciais teóricos de vozes feministas que ressignificaram a história de mulheres como a da Vilma Piedade (2017) para transgredir nossas dororidades" 3; da Safiotti (2011) em torno das perceptivas do patriarcado e das violações de gênero; da Beatriz Nascimento (1990); da Lélia Gonzalez (1984) em relação ao feminino e divisão sexual do trabalho; da Angela Davis (1981) sobre a condição da mulher na sociedade; da bell hooks (1952) com o seu pensamento atemporal sobre o patriarcado, educação feminista e mercado de trabalho; vozes essas de uma contemporaneidade que expressam de maneira significativa o modelo de cultura patriarcal que perpassa as espacialidades do ser mulher de forma tão agravante, sobretudo, em tempos pandêmicos.

Consideramos que com a pandemia da COVID-19 a situação do Brasil tornase a mais alarmante de todos os tempos com índices assustadores de mortes por dia, somando-se a uma situação política desastrosa e genocida. Desta forma, o Home Office, surge como uma das alternativas mais adoecedoras psicologicamente principalmente pelo espaço privado ter sido invadido pelo espaço público, este modelo acaba gerando confusões entre espaços, e uma carga emocional ainda mais pesada

3 Dororidades é um conceito criado pela intelectual negra Vilma Piedade, que define que a sororidade (irmandade entre mulheres) não consegue dar conta de dores pretas. Como a própria denomina em seu livro de mesmo título, a autora se identifica ao final de sua obra "Sobre a Autora em Primeira Pessoa" Maria Piedade é uma mulher preta, brasileira e feminista. 
para mulheres que de forma presencial, durante a pandemia da COVID-19, se dividem expressamente entre os dois espaços.

Desempenhar o papel de cuidar da educação das crianças alinhadas à divisão sexual do trabalho, ou, enquanto "mães solo" convivem com a dupla realidade do trabalho não remunerado do lar, em colisão com o espaço público. A desordem dos espaços sugere como a falta de redes de apoio reflete o enfrentamento de uma nova jornada de retrocessos na sobrecarga do trabalho feminino e da educação. Em que aplicativos de vídeo chamadas, câmeras fechadas, e a escassez de redes de apoio confere a possibilidade de uma violência de gênero interseccionada internamente a um debate em que o espaço do lar se torna o espaço do trabalho, uma das inúmeras perspectivas da solidão feminina.

\section{ENTRE ESTIGMAS E SIMBOLISMOS}

O que é o patriarcado? Como o corpo masculino é visto socialmente? Como o masculino desenvolve uma construção hierarquizante para o feminino? São perguntas como essas que serão respondidas durante este capítulo para entendermos a relação do masculino com o feminino e a carga emocional tensionada pela divisão sexual que estruturam a sociedade.

Patriarcado, paternalismo, pátrio poder, são termos que são correlatos quando pensamos ou pesquisamos sobre o que viria a ser patriarcado, tal interferência desses termos sugere ao paternal, a relação do pai com as estruturas sociais e, por conseguinte a dominação do homem sobre a mulher. Com isso, a língua portuguesa culturalmente deixa explícita os resquícios de uma herança resultante de um sistema patriarcal, que marca de forma tão profunda e analítica as normas, papéis e relações construídas socialmente tendo em vista a supremacia do poder masculino.

Dominação, exploração e hierarquização são conceitos intimamente ligados de forma primeira à estrutura patriarcal, e posteriormente a variantes culturais que permeiam tais contextos de estruturação e semiose em diferentes espacialidades, porém, Saffioti (2011, p. 44) define o "[...] conceito de patriarcado, que, como o seu próprio nome indica, é o regime da dominação-exploração das mulheres pelos 
homens". Ou seja, independentemente de como se dar a relação e o sistema patriarcal de cada localidade, a experiência deste sistema sempre irá atingir seja de maior ou menor grau as mulheres e suas condições sociais atravessadas por subalternizações.

É importante ressaltar que assim como o ser mulher, o ser homem é uma variante de cada sociedade cultural, apesar de a literatura e da educação considerarem o gênero masculino um termo universal. O próprio "homem médio" sugere no direito o apagamento das mulheres que nem ao menos são citadas como um sujeito de direitos fundamentais.

Os subconscientes e consequentemente a invisibilidade das mulheres vistas como complementares dos opostos binários Pierre Bourdieu (1996) por meio do conceito do habitus transita como as estruturas coletivas constroem os hábitos, trajetórias e experiências distintas tal como,

[...] estabelecem a diferença entre o que é o bom ou é mau, entre o bem e o mal, entre o que é distinto e o que é vulgar, etc., mas elas não são as mesmas. Assim, por exemplo, o mesmo comportamento ou o mesmo bem pode parecer distinto para um, pretensioso ou ostentatório para outro e vulgar para um terceiro (BOURDIEU, 1996, p. 22).

Desta maneira, a sociedade constrói relações simbólicas de dominação e exploração sobre os sujeitos mulheres e homens em um panorama que dividem o capital simbólico, a linguagem e o sexo biológico como condutores de papeis hierarquizantes sob a dominação do masculino.

\footnotetext{
As construções simbólicas oriundas dessas concepções indicam uma suposta inferioridade feminina determinada por um corpo mais frágil, reprodutiva. Por isso, as mulheres são vistas como ligadas ao mundo da casa, ao doméstico e ao cuidado dos filhos. A capacidade corporal feminina relacionada à reprodução da espécie humana delimita o espaço da mulher na vida em sociedade; seu papel social de "cuidadora" confere-Ihe uma posição hierárquica inferior em relação aos homens publicamente ativos e provedores. À primeira vista e tomando representações comuns, seria possível dizer que os homens estariam na esfera da vida produtiva, enquanto as mulheres na esfera da vida reprodutiva. (SAYÃO, 2003, p. 122-123, grifo nosso).
} 
A submissão feminina parte de uma premissa que o corpo feminino precisa ser sempre dominado, controlado. Mas, porque um corpo que cuida, precisaria ser controlado? Armadilhas como essa estão a todo o momento estruturadas de forma invisível ou não, na religiosidade, na educação das crianças, no capital simbólico de produtos de beleza, escondido entre a sessão 3 das taxas rosas ${ }^{4}$, nas mídias de massas, que servem de base para que essas estruturas permanecem camufladas e intactas na conservação do patriarcado.

Os problemas da mulher surgem desde o princípio da vida, de acordo com as diversas mitologias sobre a criação do mundo. Na mitologia bantu, depois da criação do homem e da mulher, não houve maldição nem pecado original. Mas foi o homem que surgiu primeiro, ganhando, deste modo, uma posição hierarquicamente superior, que lhe permite ser governador dos destinos da mulher. Isto significa que a difícil situação da mulher foi criada por Deus e aceite pelos homens no princípio do mundo. (CHIZIANE,2003, p.199)

As narrativas mitológicas, e as histórias não contadas sobre o ponto de vistas das mulheres brancas e negras foram pontos essenciais para a construção de símbolos hierarquizantes, um opressor e oprimido; o dominante e o dominado; o complemento e o complementar; estabelecendo assim que a equidade e igualdade de sujeitos seria um inimigo perigoso para um possível fim da dominação patriarcal. A educação surge como um dos caminhos importantes para a perpetuação de tais códigos e relações dominantes na sociedade.

Por isso a educação feminista pautada nos princípios de bell hooks confirma, é uma forma de libertação das mulheres e homens, a autora sugere que o patriarcado também é violento e adoecedor para os homens, pois para que a dominação das mulheres aconteça é necessário o uso da força e de inúmeras violências morais, sociais, psicológicas dentre outras. Assim, bell hooks comenta:

A maioria dos homens acha difícil ser patriarca. A maioria dos homens fica perturbada pelo ódio e pelo medo de mulher e pela violência de

${ }^{4} \mathrm{O}$ termo refere-se as sessões de mercado que incorpora produtos com diferentes preços para homens e mulheres. A taxa rosa representa um preço final mais caro a produtos destinados a mulheres que geralmente estão dispostos na embalagem e produtos na cor rosa. A exemplo desde lâminas de barbear até produtos de beleza. 
homens contra mulheres, até mesmo os homens que disseminam essa violência se sentem assim. Mas eles têm medo de abrir mão dos benefícios. Eles não têm certeza sobre o que vai acontecer com o mundo que eles já conhecem tão bem, se o patriarcado mudar. Então acham mais fácil apoiar passivamente a dominação masculina, mesmo quando sabem, no fundo, que estão errados. (hooks, 1952, p.14).

Estereótipos são construídos socialmente fazendo com que o homem persista nos silêncios e se sinta mais confortável tendo atitudes dentro da "caixa". Desta maneira, o sexismo limita os subconscientes e as práticas experienciadas por homens e mulheres, "Homens e mulheres não são uma - coleção ou duas coleções - de indivíduos biologicamente distintos. Eles formam dois grupos sociais que estão engajados em uma relação social específica: as relações sociais do sexo" (KERGOAT, 2000, p.55) em um lugar em que o masculino e feminino convivem dentro de uma esfera tensionada de papéis. Essa mesma autora afirma que "Estas, como todas as relações sociais, têm uma base material, no caso o trabalho, e se exprimem através da divisão social do trabalho entre os sexos, chamada, de maneira concisa, divisão sexual do trabalho" (Ibidem, p.55). O que contribui para a distorções de valor de trabalho e sobre qual tipo de trabalho deve ser remunerado ou não, como veremos adiante.

\section{EXPERIÊNCIA DE MULHERES NA PANDEMIA DA COVID-19}

Símbolo de afeto; cuidado com os afazeres domésticos; a cuidadora do lar e da família; o cuidado romântico. Em todas as palavras citadas até aqui, o "cuidado" aparece como um marcador da experiência de mulheres tanto no espaço privado como público. O problema é quando a palavra "cuidado" afeta de maneira violenta a condição de gênero, o ser que cuida não precisa de cuidados? É com essa pergunta que muitas mulheres neste exato momento podem estar se fazendo enquanto durar a pandemia da COVID-19, em que o "cuidado" para o outro the confere a sobrecarga física e emocional que atravessa a perspectiva do ser mulher.

Desta maneira, a divisão sexual do trabalho consiste como uma das primordiais construções sociais em benefício ao patriarcado, que surge como solução de manter 
a mulher na esfera do lar e o homem na esfera pública. "Assim, assiste-se à remodelação das novas formas de organização do trabalho e da divisão sexual do trabalho, mas manutenção de formas de segregação e hierarquização pré-existentes" (HIRATA, 2010) Favorecendo os homens no crescimento profissional e o isentando das atividades domésticas a fim de, condicionar os papéis sociais e manter o patriarcado como sujeito dominante dos assuntos como política, capitalismo, mercado de trabalho afastando-o da esfera doméstica e das responsabilidades com relação ao lar e educação das crianças, principalmente pelo fato do capitalismo não remunerar a sobrecarga da esfera doméstica.

A Pesquisa Nacional por Amostra de Domicílios - PNAD, em 2019, antes da pandemia da COVID-19, em sua coleta de dados traz um demonstrativo de que mulheres ainda são as que mais dedicam o seu tempo às atividades domésticas, mesmo quando inseridas no mercado trabalho. Segundo a PNAD, as mulheres se dedicam a uma jornada de trabalho doméstico semanal de $10 \mathrm{~h} 24 \mathrm{~m}$ a mais em comparação a dos homens. Isso representa quase o dobro da jornada masculina, revelando também que $92 \%$ da população feminina de 14 anos ou mais realiza trabalho doméstico. Para os homens esse número cai para 78,5\%. Também são as mulheres à frente das principais atividades relacionadas aos cuidados como cozinhar $(93,5 \%)$, lavar louça $(93,5 \%)$ e cuidar das roupas $(91,2 \%)$.

Porcentagens alarmantes vinculadas a essa amostragem confirmam que a esfera do lar e o cuidado ainda continuam condicionando a mulher neste âmbito, mesmo quando esta se divide entre a esfera privada e pública na sociedade. Um outro dado apresentado durante esta pesquisa é que

[...] mulheres sem ocupação fora do domicílio, se dedicam em média 24 horas semanais aos afazeres domésticos; e os homens metade desse tempo (12,1 horas semanais),enquanto as mulheres que ocupam a esfera pública se dedicam em média 8,1 horas as atividades domésticas que os homens que também fazem parte do mercado de trabalho" (Agência IBGE, 2019).

É importante deixar claro que os dados mudam quanto à amostragem de pessoas pretas e pardas, quando falamos do cuidado para com o outro, pessoas 
pretas $(33,7 \%)$ e pardas $(33,0 \%)$ possuíam taxa de realização maior que pessoas brancas (29,7\%), sendo mais marcantes em mulheres. Enquanto cerca de $40 \%$ das mulheres pardas e pretas realizavam cuidados em 2019, a taxa de realização entre as brancas era de $33,5 \%$.

Com isso, fica nítido que as discrepâncias entre mulheres brancas e negras mudam o cenário do significado de cuidar e seus atravessamentos de raça e classe, já que mulheres negras dividem a relação do cuidado que se estende geralmente a comunidade, como vizinhos, idosos, amigos, além dos familiares. Assim, as sobrecargas físicas e emocionais colidem de diferentes maneiras e logo tais experiências durante a COVID-19 começam a demarcar o cuidado como nunca visto na história, restaurando papéis sociais para o enfrentamento de uma pandemia de saúde pública. O papel do cuidar e toda a sobrecarga que este nome carrega continuam atribuídos ao feminino e porque não pensar na divisão sexual do trabalho como solução desta problemática? Infelizmente a lógica de dominação e construção simbólica dos sujeitos é um dos pontos que interferem quando discutimos este tema.

Durante o Código Civil de 1916, era impensável direitos fundamentais para as mulheres por meio deste código, visto na Lei nº 3.071, em 1 de janeiro de 1916, conhecida como Código de Beviláquia. Parecia um caminho distante, principalmente porque a maioria dos códigos estavam sendo criados por homens brancos de alto poder aquisitivo. Consequentemente, o ser mulher estaria universalizado à mulher branca de classe alta, substancialmente em vários trechos da lei:

Se no Código Napoleônico, segundo Joseph Goy, "a tinham na conta de um ser fraco, dotado de um espírito móvel e frívolo, que se impunha proteger", no Código Beviláquia separou-se para a mulher o inciso IV, do art. $6^{\circ}$, em que figuravam os relativamente incapazes (menores de 18 anos, silvícolas, pródigos etc.). (JUNQUEIRA, Eduardo, CPDOCFGV).

Mediante a comparação do Código Napoleônico e o Código de 1916 (Código de Beviláquia), o estereótipo instituído com relação a tais códigos seria de uma mulher branca e de poder aquisitivo. A mulher negra em nenhuma hipótese seria considerada como um ser fraco, incapaz ou que precisa de proteção. Logo, a mulher negra, não 
integrava ao ser mulher, e muito menos como sujeito de direitos sociais advindas da desumanização resultante de processos civilizatórios e escravocratas.

Ainda segundo Eduardo Junqueira junto ao CPDOC-FGV, o Código Civil de 1916 foi alterado em 1919 quando a mulher ocupa o mercado de trabalho ou espaço privado e ideais de igualdade, e alguns outros avanços em 1962, não sendo consideradas mais como incapazes perante a lei, no ano de 1977 a Lei no 6.515 no art. 267, permite-se o divórcio modificando também as relações que o matrimônio representava nas condições do ser mulher. É importante salientar aqui que a conquista do mercado de trabalho para as mulheres brancas não é uma novidade. As mulheres negras SEMPRE ocuparam essa esfera em um modelo altamente exploratório, hostil, animalizado e sexualizado, assim sendo, a libertação para as mulheres brancas ainda aprisionava as mulheres negras ${ }^{5}$.

A pandemia da COVID-19 entre o início de 2020 e 2021 volta a abrir fissuras sociais sobre as desigualdades que nunca estiveram tão em evidência. Desigualdades que tencionam gênero, raça e classe, a valorização de profissionais do cuidado e principalmente do cuidado feminino. O "Fique em casa" surge para quem cuidar? Segundo, Denise Pimenta, 2020 em Pandemia é coisa de Mulher: Breve ensaio sobre o enfrentamento de uma doença a partir de vozes e silenciamentos dentro das casas, hospitais e na produção acadêmica, relata:

Geralmente, epidemias e pandemias afetam muito mais mulheres do que homens, visto que estas são as responsáveis pelo cuidado com doentes e com a gestão dos recursos domésticos, o que as sobrecarregam fisicamente e psicologicamente. Sabendo que toda pandemia é generificada, racializada e tem classe social, pode-se dizer que a crise do novo coronavírus no Brasil tem cara de mulher preta e periférica e, muitas vezes, deficiente. Ou seja, a pandemia afeta, mesmo que não mate, a base da pirâmide social brasileira. (grifos nossos).

\footnotetext{
5 Além disso, uma vez que as mulheres negras, enquanto trabalhadoras, não podia ser tratadas como "sexo frágil" ou "dona de casa", os homens negros não podiam aspirar á função de "chefes de família", muito menos á de "provedores da família". Afinal, homens, mulheres e crianças eram igualmente "provedores" para a classe proprietária de mão de obra escrava. (DAVIS, 1981, p. 20)
} 
A pandemia ressignificou e valorizou o cuidar que se tornou indispensável para os enfermos da COVID-19 e a mudança de relações sociais com base no isolamento social como medida de proteção da família e parentes próximos. Em contradição a isso o lar que é sinônimo de afeto também em contrapartida se converte em desafeto para as mulheres em especial sobre o trabalho reprodutivo invisibilizado. A emancipação feminina parece falhar quando as mulheres retornam ao ambiente do lar e reproduzem novamente os afazeres domésticos que há tanto tempo tentaram se desvincular. A pandemia já é um grande indicativo de retrocessos e sobrecargas preocupantes.

Em Cuidados no Brasil: conquistas, legislação e políticas públicas (2020),

O relatório da Oxfam (2020), divulgado durante o Fórum Econômico Mundial de Davos (2020), 42\% das mulheres no mundo (contra apenas $6 \%$ dos homens) não têm emprego remunerado porque são responsáveis pelo trabalho de cuidado em sua casa. Dentre as 67 milhões de pessoas que fazem trabalho doméstico, $80 \%$ são mulheres; dessas, $90 \%$ não tem acesso à seguridade social e mais da metade delas não tem uma jornada de trabalho semanal com definição de limite de horas.

O que mais preocupa é que essas mesmas mulheres continuam vítimas de um sistema patriarcal que se constrói tendo em vista este trabalho reprodutivo "invisível". Além disso, dados como este revelam que apesar de localidades distintas a condição do ser mulher muda de lugar, mas dificilmente de sujeito.

Portanto, não mais que outras formas de divisão do trabalho, a divisão sexual do trabalho não é um dado rígido e imutável. Se seus princípios organizadores permanecem os mesmos, suas modalidades (concepção de trabalho reprodutivo, lugar das mulheres no trabalho mercantil, etc) variam fortemente no tempo e no espaço (KERGOAT, 2000, p.56).

"Assim como as obrigações maternas de uma mulher são aceitas como naturais, seu infinito esforço como dona de casa raramente é reconhecido no interior da família. As tarefas domésticas são, afinal de contas, praticamente invisíveis". (DAVIS, 1991, p. 225). Quantas vezes já ouvimos falar “... ela não trabalha, é apenas dona de casa". Visto isso, culturalmente o trabalho reprodutivo não é enxergado como 
trabalho, afetando ainda mais o modo como se constrói a divisão sexual do trabalho e consequentemente na parceria de mulheres e homens como rede de apoio, pois esse mesmo estigma sobre o trabalho reprodutivo que não gera valor monetário é desvalorizado, logo, é visto como um lugar sem ocupação.

A economia feminista comenta sobre este fenômeno do cuidar que ultrapassa as relações afetivas e trabalhosas, porém um trabalho que sustenta as bases do patriarcado e capitalismo.

Foi a partir da tomada de consciência de uma opressão específica: tornou-se coletivamente "evidente" que uma enorme massa de trabalho era realizada gratuitamente pelas mulheres; que esse trabalho era invisível; que era feito não para si, mas para os outros e sempre em nome da natureza, do amor e do dever maternal. (KERGOAT, 2000, p.56)

Segundo a Agência IBGE de notícias,

\begin{abstract}
Mulheres que necessitam conciliar trabalho remunerado com os afazeres domésticos e cuidados, em muitos casos, aceitam ocupações com carga horária reduzida. Em 2019, cerca de um terço das mulheres $(29,6 \%)$ estavam ocupadas em tempo parcial (até 30 horas semanais de trabalho), quase o dobro do verificado para os homens (15,6\%), Às regiões Norte e Nordeste apresentaram as maiores proporções de mulheres ocupadas em trabalho parcial: 39,2\% e $37,5 \%$, respectivamente.
\end{abstract}

Com isso, a redução de jornadas de trabalho e na maioria das vezes quando as mulheres em concorrência de algum cargo ainda são perguntadas se esta é solteira ou casada e se têm filhos, ou não, diz muito sobre a relação da esfera doméstica com o mercado de trabalho e a dupla jornada, posto que, para ocupar o mercado de trabalho o capitalismo exige-se dedicação total, assim como acontece com os homens, a diferença é que este se apoia na mulher como rede de apoio permitindo sua dedicação exclusiva para que se mantenha no mercado de trabalho.

A liberdade feminina não começa com o ingresso ao mercado de trabalho, o que é decepcionante de se pensar. Mulheres são as que ainda recebem menos que os homens mesmo que em cargos equivalentes, sofrem assédio moral, sexual no 
trabalho, violência institucional e psicológica, sem falar quando essas mesmas mulheres são agredidas por seus parceiros na esfera doméstica e ainda exercitam o cuidado com o lar e as crianças. Quando "mães solo" assumem uma carga de provedora e cuidadora do lar, ou no contrato de outras mulheres para assumir essa esfera. Como Kergoat, 2000 conceitua muito bem existe uma dualização do emprego feminino, além de identificar a relação social e identidade individual e coletiva como processos de complexibilidade e de não evolução no mesmo ritmo seja um dos problemas para categorias dominantes explodirem. Assim as relações norteadas através da raça e classe também modificam essas trajetórias que consistem também na violência da divisão sexual do trabalho, desempregos e precauções com o contágio viral acentuadas em tempos como o da COVID-19.

Desse modo, ser autossuficiente economicamente nem sempre é liberdade. Com isso, hooks (1952, p. 83) comenta que,

Inúmeras mulheres se sentiram furiosas, porque foram incentivadas pelo pensamento feminista a acreditar que encontrariam a libertação no mercado de trabalho. O que mais aconteceu foi se darem conta de que trabalhavam longas jornadas em casa e longas jornadas no trabalho.

Com isso, mesmo mulheres ocupando o papel de provedora da família, ainda assim, os homens continuam beneficiados por este sistema capitalista, porque a mulher continua a ocupar o trabalho na esfera do lar, Segundo (Hirata, 2010, p. 4-5), coexiste a relação do habitus, pois "o care (cuidado de crianças, idosos, deficientes físicos e doentes), como atividade profissional, tem um caráter explosivo, pois questiona a gratuidade do trabalho doméstico, a servidão voluntária efetuada no espaço privado". Agora de dois modos sustentando as bases econômicas com o trabalho reprodutivo e produtivo, assim a liberdade nunca se fez tão utópica e solitária, principalmente no que toca mulheres negras. 


\section{A SOLIDÃO DA MULHER NEGRA, DISCUTINDO SOBRE "DORORIDADES"}

Imagine a seguinte cena, é domingo dia de futebol com os amigos e de jogar baralho na sala de estar. As mulheres estão na cozinha fazendo petiscos para seus maridos, crianças e amigos e no final do dia precisam arrumar a bagunça do lar, cuidar das crianças para na segunda-feira retornar a jornada de trabalho na esfera pública muitas vezes já esgotadas para recomeçar a semana. Cenas como essas em algum momento da infância já foram presenciadas por algum de nós seja na nossa casa, na casa do vizinho, com parentes ou amigos.

Segundo a autora Luiza Bairros, existem três aspectos que norteiam a descrição acima, a natureza feminina, experiência e a maternidade.

Cabe notar que essa definição ao mesmo tempo em que reforça um dos aspectos definidores do feminismo em relação a outros sistemas de pensamento - a importância da subjetividade em oposição a objetividade também abre a porta para as generalizações. Isto associado ao maior acesso aos meios de propagação de ideias por certos grupos sem dúvida contribuiu para que experiências localizadas fossem tomadas como parâmetro para as mulheres em geral (BAIRROS, 1995, p.2).

A divisão sexual do trabalho começa a ser reproduzida como natural e normalizada ao feminino, para as mulheres negras essa esfera do abandono e solidão, revela as dores de ser mulher.

Um fato curioso é "... as mulheres negras dificilmente eram "mulheres" no sentido corrente do termo" (DAVIS, 1981, p. 20), a bell hooks também comenta em suas obras sobre este efeito na vida de mulheres negras que são as mais abandonadas pelos seus parceiros e encontram rede de apoio com suas mães, ou de outras mulheres para que possam se manter no mercado de trabalho assumindo por um período a ausência do lar, afazeres domésticos e cuidados com as crianças. Mulheres dando as mãos a outras mulheres a sororidade como a Vilma Piedade (2017), sugere que não consegue dar conta de dores pretas, o conceito das dororidades, se somatiza em dores de resistir dentro da pele negra. 
Por esse pensamento formulado, a mulher seria um homem, embora não sendo total. Seria ciclicamente homem, conforme seu próprio ciclo natural (puberdade e maternidade). Fora desses estados, sua capacidade de trabalho estaria a reboque da necessidade do desenvolvimento econômico (mão de obra anexada ou excludente de acordo com as variações da Economia). Fora desses espaços, ou mesmo aí ela não o é. Será a razão de lugar, ou exercerá sua razão fora do campo produtivo. (NASCIMENTO, Jornal Maioria Falante, 1990).

Assumir o papel de provedora da família para a mulher negra causou comentários e idealizações de que ela estaria acima do homem negro. Esta relação também interfere na divisão sexual do trabalho. Segundo (Davis, 1971, p. 29), a escravidão foi um salto neste processo porque a esfera do lar seria a única oportunidade de vivenciar experiências de forma humana, as mulheres negras dividiam tarefas com os homens negros e também eram consideradas como trabalhadoras não sendo tratadas como donas de casa, já que também trabalhavam fora da esfera do lar.

Segundo a Pesquisa Nacional por Amostras de Domícilios Contínua (PNAD, 2019),

A maior taxa de realização de cuidados de pessoas, em 2019, ocorreu entre as mulheres com ensino fundamental completo e médio incompleto $(41,1 \%)$, ao passo que, entre os homens, a menor taxa ocorreu entre aqueles sem instrução ou com fundamental incompleto $(21,3 \%)$.

O cuidar também está relacionado ao nível de instrução, quanto menor, maior serão as chances de mulheres ou homens assumirem este papel invisível perante a economia e sociedade com um todo, ou seja, a relação de raça e classe rege este não lugar.

Numa sociedade onde a divisão racial e a divisão sexual do trabalho fazem dos negros e das mulheres trabalhadores de segunda categoria, no conjunto dos trabalhadores já por demais explorados (afinal, sobre quem recai o peso da recessão?); numa sociedade onde 0 racismo e 0 sexismo, enquanto fortes sustentáculos da ideologia de dominação fazem dos negros e das mulheres cidadãos de segunda classe, não é difícil visualizar a terrível carga de discriminação a que está sujeita a mulher negra. (GONZÁLEZ, 1984, p. 98, grifos nossos). 
Visto isso, a sobrecarga com o lar, a discriminação e exploração no mercado de trabalho para as mulheres negras e ao mesmo tempo donas de casa, as trabalhadoras do ambiente reprodutivo demanda em dores, e principalmente da rede de empatia e solidariedade.

Portanto, o mesmo amor que cuidava, colocava estas mulheres e meninas em situações de vulnerabilidade e risco. Adoecendo, muitas destas mulheres também eram cuidadas por outras muitas mulheres, que também teciam a trama de cuidado doméstico que, por sua vez, era a mesma rede de risco e transmissão da doença. O mesmo cuidado que salvava, também matava. (PIMENTA, 2020, p. 4)

Já que pensar o amor dentro do lar também é um processo de dor e culpa. $O$ conceito da Dororidade, criado pela Vilma Piedade informa a relação dessas dores com o machismo como um ponto comum entre mulheres brancas e negras, “... Contudo, quando se trata de Nós - Mulheres Pretas, tem um agravo nessa dor. A Pele Preta nos marca na escala inferior da sociedade. E a Carne Preta ainda continua sendo a mais barata do mercado." (Piedade, 2017, p. 17).

Esta mesma Carne Preta, morre todos os dias por bala achada ${ }^{6}$, pela desigualdade social, desemprego, fome e vítimas da COVID-19, por vezes, tem na cor e na classe quem poderá sobreviver a tempos em que a pobreza viral, são vias de contágio e contam com os cuidados femininos principalmente das mulheres pretas e periféricas. Desta maneira, (hooks, 1982, p. 86), toca em uma ferida social que muda a lógica do trabalho reprodutivo e a relação de autossuficiência econômica, ao dizer que o Estado deveria subsidiar um salário para mulheres e homens que estivessem na conjuntura do lar. Além disso, criar programas de educação e qualificação incentivando que pessoas que se encontram nesta esfera possam terminar o ensino fundamental, médio ou graduação em casa, considerando o trabalho reprodutivo visível e valorizado, quem cuida também merece ser cuidado e talvez não muito longe a divisão sexual do trabalho mudaria a condição do ser mulher.

${ }^{6}$ É um termo utilizado para identificar e contradizer o fenômeno das "balas perdidas". Visto que, a bala achada geralmente encontra como destino um corpo, o corpo negro como alvo de violência e de vidas ceifadas. 


\section{CONSIDERAÇÕES FINAIS}

A COVID- 19 representa um marco histórico ao tempo que paralisa a sociedade, também permite olhar criticamente para as relações de gênero, raça e classe, na esperança de mudanças quanto ao cuidar e seus perigos. $O$ isolamento social e as medidas de contenção e difusão do vírus realocaram perspectivas de solidão e distanciamento, consequentemente a isto jornadas exaustivas quando o espaço público invade o privado, e as redes de apoio às mulheres começam a se restringir como forma de não propagação viral.

É fundamental que a solidariedade tanto feminina quanto masculina, busque alternativas de superação de estigmas dominantes, como provoca (HIRATA, 2010, p.6), "Será que a luta pela igualdade é uma luta específica? Será que a luta pela justiça é uma luta específica?" Educar meninas e meninos; mulheres e homens com base na educação e economia feminista desde a infância demonstra a necessidade de construir uma luta coletiva com o objetivo de compreender que mulheres e homens devem assumir os mesmos papéis sociais que independam de gênero ou sexualidade. Crianças precisam aprender desde sempre a ser rede de apoio na divisão sexual do trabalho doméstico, e entender que os afazeres domésticos ou o cuidado com o outro não é uma "ajuda", ou "obrigação" das mulheres que contextualizam aquele lar, mas um papel mais que social que conecta a intimidade familiar de forma conjunta.

Desta maneira, as sobrecargas seriam menores e o lar não mais seria 0 ambiente adoecedor que violenta fisicamente e psicologicamente as mulheres, a relação de horizontalidade solucionaria não por completo a reconstrução de papéis, mas evitaria a reprodução de símbolos e construções em consequência da COVID-19 ao qual podemos repensar e, sobretudo, reavaliar o tempo de cuidar ao tempo de mudar.

\section{REFERÊNCIAS}

ABREU DE OLIVEIRA, F.; MARQUES DE QUEIROZ, F.; DINIZ, M. I. Divisão Sexual do Trabalho entre Homens e Mulheres no contexto da pandemia da Covid-19.

Revista Inter-Legere, Natal, v. 3, n. 28, p. 01-22. Disponível em: $<$ https://periodicos.ufrn.br/interlegere/article/view/21486>. Acesso em: 18/05/2021. 
AGÊNCIA IBGE DE NOTÍCIAS. Em média, mulheres dedicam 10,4 horas por semana a mais que os homens aos afazeres domésticos ou ao cuidado de pessoas. Estatísticas Sociais, 2020. Disponível em:< https://agenciadenoticias.ibge.gov.br/agencia-sala-de-imprensa/2013-agencia-denoticias/releases/27877-em-media-mulheres-dedicam-10-4-horas-por-semana-amais-que-os-homens-aos-afazeres-domesticos-ou-ao-cuidado-de-pessoas $>$. Acesso em: 02/05/2021.

AGÊNCIA IBGE DE NOTÍCIAS. Estatísticas de Gênero: ocupação das mulheres é menor em lares com crianças de até três anos. Estatísticas Sociais, 2021 Disponível em: <https://agenciadenoticias.ibge.gov.br/agencia-sala-deimprensa/2013-agencia-de-noticias/releases/30172-estatisticas-de-generoocupacao-das-mulheres-e-menor-em-lares-com-criancas-de-ate-tres-anos $>$. Acesso em: 02/05/2021.

AGÊNCIA PATRÍCIA GALVÃO. Dividir as tarefas domésticas é dizer não à violência contra a mulher. Folha de Pernambuco, 2020. Disponível em: < https://agenciapatriciagalvao.org.br/mulheres-de-olho/trabalho/dividir-as-tarefasdomesticas-e-dizer-nao-a-violencia-contra-a-mulher/?print=pdf >. Acesso em: $14 / 05 / 2021$

BAIRROS, Luiza. Nossos Feminismos Revisitados. Revista Estudos Feministas, v.3, n.2, Florianópolis, segundo semestre, p.458-463. Disponível em: < https://www.geledes.org.br/wpcontent/uploads/2014/04/Nossos_Feminismos_Revisitados_Luiza_Bairros.pdf> Acesso em: 12/10/21

BEAUVOIR, Simone de. O Segundo sexo. Rio de Janeiro, Nova Fronteira, 2009.

CHIZIANE, Paulina. Eu, Mulher ... por uma nova visão do mundo. Revista do Núcleo de Estudos de Literatura Portuguesa e Africana da UFF. Niterói, v.5, n.10, p.199-205, jan-jun, 2013.

2013. Disponível em: < https://periodicos.uff.br/revistaabril/article/download/29695/17236>. Acesso em: 10/05/2021.

Cuidados no Brasil: Conquistas, legislação e políticas públicas. São Paulo: Friedrich Ebert Stiftung (FES) Brasil, Dezembro de 2020: Disponível em: <http://library.fes.de/pdf-files/bueros/brasilien/17083.pdf> .Acesso em: 14/05/2021.

DAVIS, Angela. Mulheres, Raça e Classe.1.ed. São Paulo: Boitempo, 2016. GONZALEZ, Lélia. Por um feminismo afro-latino-americano: ensaios, intervenções e diálogos. 1. ed. Rio de Janeiro: Zahar, 2020. 
HIRATA, Helena. Novas Configurações da Divisão Sexual do Trabalho. Revista Tecnologia e Sociedade, Curitiba, v.6, n.11, p.1-7, jul-dez, 2010. Disponível em: < https://periodicos.utfpr.edu.br/rts/article/view/2557> Acesso em: 12/10/21.

Hooks, bell. O Feminismo é para todo mundo: políticas arrebatadoras. 13. ed. Rio de Janeiro: Rosa dos Tempos, 2020.

JUNQUEIRA, Eduardo. Código Civil de 1916. Disponível em: < https://cpdoc.fgv.br/sites/default/files/verbetes/primeirarepublica/C\%C3\%93DIGO\%20CIVIL\%20DE\%201916.pdf> . Acesso em: 20/05/2021.

NASCIMENTO, Beatriz, A mulher negra e o amor. Jornal Maioria Falante. Rio de Janeiro, Fevereiro - Março, 1990. Disponível em: <https://www.geledes.org.br/amulher-negra-e-oamor/?gclid=CjwKCAjwzruGBhBAEiwAUqMR8Eu2QOksZ2FPB7yDnYY9cZ7OCpRb si8x7mVXSevG5ChtEmayhBsjGBoC5aUQAvD_BwE>.Acesso em: 25/05/2021.

PIEDADE, Vilma. Dororidade. São Paulo: Editora Nós, 2017.

PIMENTA, Denise. Pandemia é coisa de mulher: Breve ensaio sobre o enfrentamento de uma doença a partir das vozes e silenciamentos femininos dentro das casas, hospitais e na produção acadêmica. Tessituras, Pelotas, v.8, n.1, p.8-19, jan-jun, 2021. Disponível em:

<https://periodicos.ufpel.edu.br/ojs2/index.php/tessituras/article/view/18900>.Acesso em: 12/05/2021.

PNAD CONTÍNUA. Outras formas de trabalho. Rio de Janeiro, 2019. <Disponível em:https://biblioteca.ibge.gov.br/visualizacao/livros/liv101722_informativo.pdf>.Acess o em: 02/05/2021.

KERGOAT, Daniele. Divisão sexual do trabalho e relações sociais de gênero. Tradução: Miriam Nobre. In: EMÍLIO, Marli et al. (Orgs.). Caderno Trabalho e cidadania ativa para as mulheres: desafios para as políticas públicas. São Paulo, no 3, p. 55-64, dez.

REVISTA VEJA. Marcela Temer: bela, recatada e "do lar". Editora Abril: 18 de abril de 2016. Disponível em: <https://veja.abril.com.br/brasil/marcela-temer-belarecatada-e-do-lar/>.Acesso em: 02/05/2021.

SAFFIOTI, Heleieth. Gênero, patriarcado, violência. São Paulo: Editora Fundação Perseu Abramo, 2004 - (Coleção Brasil Urgente).

SAYÃO, Deborah. Corpo, poder e dominação: um diálogo com Michelle Perrot e Pierre Bourdieu. Revista Perspectiva. Florianópolis, v.21, n.1, p. 121-149, jan-jun, 2003. 